\title{
Young Children's Conceptions of Rainfall: A Study of Their Oral and Pictorial Explanations
}

\author{
José Domingo Villarroel ${ }^{1} \&$ Iker Ros $^{2}$ \\ ${ }^{1}$ University College of Teacher Training in Bilbao, University of The Basque Country, Leioa, Spain \\ ${ }^{2}$ University College of Teacher Training in Vitoria-Gasteiz, University of The Basque Country, Vitoria-Gasteiz, \\ Spain \\ Correspondence: José Domingo Villarroel, University College of Teacher Training in Bilbao, University of The \\ Basque Country, Barrio Sarriena s/n, 48940-Leioa, Spain. Tel: 34-946-014-645. E-mail: txomin.villarroel@ehu.es
}

Received: May 19, 2013 Accepted: June 28, 2013 Online Published: July 16, 2013

doi:10.5539/ies.v6n8p1 URL: http://dx.doi.org/10.5539/ies.v6n8p1

\begin{abstract}
This study examines the conceptual understanding of the mechanisms of rainwater among elementary educational level children by means of two different experimental procedures: a semi-open questionnaire and drawings. The sample study comes from four different schools located in The Basque Autonomous Community (Spain) and is comprised of 124 children enrolled in two different educational levels: the final course of preschool education (5-6 year old children) and the first course of primary education (6-7 year old children). This paper describes the differences with regard to the performance in the drawing tasks among children from the different educational levels considered in the investigation. However, no difference was found concerning their verbal explanations. The results are discussed in the light of a socio-cultural standpoint. Therefore, the study attempts to contribute to the growing body of investigations that aim to understand the process of the comprehension of natural phenomena during the early education.
\end{abstract}

Keywords: science education, early education, geoscience, cognitive development, language, atmospheric phenomena

\section{Introduction}

In light of the research activity carried out during the last decade, it is believed that basic scientific thinking skills of preschool and elementary school children may have been underestimated by traditional views about children's inability to conceptually grasp scientific notions (Bullock, Sodian \& Koerber, 2009; Ginsburg \& Golbeck, 2004; Zimmerman, 2007). Consequently, the competence of young children with respect to concept-based learning of scientific concepts has been currently indicated as one of the relevant avenues for expanding our knowledge of the way such concepts are acquired (Duschl \& Hamilton, 2011).

In this sense, the way that children acquire an understanding of natural phenomena is a research topic that is attracting much more attention than ever before. (Dockrell, Braisby \& Best, 2007; Dove, Everett \& Preece, 1999; Hannust \& Kikas, 2010; Inan, Trundle \& Kantor, 2010; Schroeder, Graham, McKeough, Stock, Palmer, 2010; Straatemeier, van der Maas, Jansen, 2008).

Consequently, there is a growing body of research which offers considerable evidence regarding the most significant elements of children's understanding of concepts related to: physics (Kloos, Fisher, \& Van Orden, 2010; Frappart \& Frède, 2010), biology (Devereaux, Poling \& Evans, 2004; Snaddon, Turner \& Foster, 2008) and astronomy (Hannust \& Kikas, 2010; Trundle, Atwood \& Christopher, 2007; Vosniadou, \& Brewer, 1994). However, in accordance with Saçkes's report (Saçkes, Flevares \& Trundle, 2010) little research has been conducted in the field of atmospheric phenomena (see also, Christidou \& Hatzinikita, 2006) and the research that has been carried out specifically focuses on students in the upper levels of the compulsory education system (Henriques, 2002; Lewis, van der Hoeven Kraft, Bueno, Watts, Baker, Wilson \& Lang, 2010 ; Shepardson, Wee, Priddy, Schellenberger \& Harbor, 2009).

Similarly, no research has been carried out regarding very young children's understanding of atmospheric phenomena in the socio-cultural context in which this study has been conducted (that is, the Basque Country and, more broadly, Spanish educational context). However, some significant research has been carried out with 
subjects of more advanced ages (Márquez, Izquierdo \& Espinet, 2003; Márquez \& Bach, 2007; Reyero, Calvo, Vidal, García \& Morcillo, 2007). In this respect the interest that research based on drawings by children has from an international perspective should be emphasized, especially in light of the advantages that this experimental design provides for worldwide comparison of data (Prokop \& Fancovicová, 2006).

Moreover, the above mentioned lack of research with respect to the analysis of the evolving understanding of the mechanisms of rainfall during the early stages of school is surprising bearing in mind that atmospheric phenomena, and in particular rainfall, are widely used resources in elementary education levels for work related to both the natural sciences and metric aspects of mathematical understanding (Fernández \& Rodríguez, 2006; Plasencia \& Varela 2006). Furthermore the accurate comprehension of the mechanisms of rainwater is connected to an understanding of the notion of the water cycle (Henriques, 2002; Goñi \& Villarroel, 2005) which is one of the most relevant scientific concepts linked not only to Earth science but also to physic, chemistry (Shepardson et al., 2009; Uyen, Payne, Whitley 2010) and environmental education (Bodzin, Shiner \& Weaver, 2010).

In this vein, a better understanding of the process of comprehension of the mechanisms of rainfall, and hence the water cycle itself, could contribute to a more accurate knowledge of the general processes involved in the acquisition scientific thinking skills during early childhood.

There is a complementary matter regarding research on the understanding of scientific notions during childhood which involves the design of methodological approaches that can be used effectively with such young children.

In what could be considered the latest and most in-depth attempt to investigate very young children's comprehension on the mechanisms of rainfall, Sackes et al. (2010) favored a solely semi-structured interview method which was designed specifically for carrying out an investigation with 4-6 year old children. Christidou and Hatzinikita (2006) used a similar procedure to investigate children's ideas about the issue of rain formation, in which pictorial representations were simply a motivational technique used to encourage children to express their thoughts.

However, as some scholars have pointed out, experimental designs involving both drawing techniques and verbal reports are very useful procedures when one attempts to explore children's ideas about scientific concepts (Panagiotaki, Nobes \& Potton, 2009). Thus, drawings have been successfully applied to research the way students understand a wide range of scientific concepts; for example, the way notions of forests and their inhabitants are conceptualized (Snaddon, Turner \& Foster, 2008; Strommen, 1995), comprehension of plants and the need they have to grow (McNair \& Stein, 2001), understanding of the human body (Prokop \& Fancovicová, 2006), ideas about technology (Rennie \& Jarvis, 1995). The approach has also been used to examine children's stereotypes towards scientists (Susan, Losh, Wilke \& Pop 2008). Likewise, depictions produced by children have been useful to study their acquisition of knowledge about the Earth (Hannust \& Kikas, 2010) and also to look into students' ideas about watersheds (Shepardson, Harbor \& Wee, 2005).

A number of reasons can be brought forward to support the thesis that drawing is a very useful technique for exploring very young children's ideas. For example, drawings made by a child are thought to be a mirror image of a child's representational development (Cherney, Seiwert, Dickey, \& Flichtbeil, 2006) while drawings themselves are embodied with, and carry meaning (Kress, Jewitt, Ogborn \& Tsatsarelis, 2001). Moreover, it has been reported that young children are more easily involved in drawing tasks at least in part because by means of this technique they are prevented from feeling constrained by the need to match their responses to conventional answers (Rennie \& Jarvis, 1995). Additionally, drawing activities are a useful option in order to encourage children who find difficulty in expressing themselves orally. It is easier for them to express their ideas through pictures (Holliday, Harrison \& McLeod, 2009; White \& Gunstone, 1992).

As a result of the deficiencies perceived in the previously presented research, this study sets out to achieve a more in-depth understanding of how young children give sense to natural phenomena and more specifically, how the characteristic elements of scientific accounts, typically referred to as the notion of water cycle, are integrated into their explanations regarding the phenomenon of rainfall. Additionally, age-related differences in terms of the utilization of the elements of the notion of water cycle between the age of 5 and 8 are also analyzed.

Moreover, this research project aims to evaluate whether the joint study of both children's verbal explanations and their pictorial elaborations may provide relevant data when investigating young children conceptions on natural phenomenon.

According to the preceding objectives, the research intends (a) to examine the explanations of 5 and 8 year old children regarding the phenomenon of rainfall and identify the elements related to the water cycle found in both verbal descriptions and pictorial illustrations; (b) to analyze whether children in their final year of preschool 
education (5-6) can be distinguished in terms of the utilization of these scientific elements from those who are in the first level of primary education (6-7) and, if so, (c) to determine where these differences are located, in oral descriptions or in pictorial explanations.

\section{Method}

\subsection{Participants}

This research was conducted in the Basque Autonomous Community which is one of the 19 autonomous communities and cities that comprised the Spanish state. The Basque Autonomous Community (BAC) is located in the north-east of the Iberian Peninsula. On the north, its borders are the north on the Bay of Biscay and France. Around two million people live in the BAC and it has legislative autonomy, executive and administrative powers.

A singular characteristic of the BAC is the co-existence of two official languages: Spanish (which it shares with the other autonomous territories of the Spanish state) and Basque, which is currently used by around 900,000 people in the Basque Autonomous Community, the Regional Community of Navarre (also in Spain) and south western France (Larrea, 2009).

Regarding the educational system in the BAC, table 1 breaks down the distribution of educational levels prior to university studies.

Table 1. Pre-university education system in the Basque Autonomous Community

\begin{tabular}{lll}
\hline Age & Level & Character \\
\hline $2-6$ & Preschool education & Non-compulsory \\
$6-12$ & Primary education & Compulsory \\
$12-16$ & Secondary education & Non-compulsory \\
\hline
\end{tabular}

A significant feature of the education system in BAC is that children generally start to attend school very early and most of them begin the schooling process at the preschool level. Accordingly, almost $100 \%$ of the children of the BAC are schooled from the age of 4 (Eustat, 2010).

As regards the sample of this study, it is comprised of 124 children (61 boys and 63 girls). Of these, 70 (56.8\%) were in the final stages of preschool education (5-6 year old) and 54 (43.2\%) were enrolled in the first course of primary education (6-7 year old).

This sample was obtained in four preschool and primary educational centers belonging to The Basque Autonomous Community, Spain (Salaburu, 2009; Cenoz, 1998). These centers are located in two different towns, each with more than 4,000 inhabitants.

All these schools were visited in the first quarter of 2011. Permission to conduct the interviews was obtained from the administrators of each school, and the interviews took place at the schools during normal classroom hours. The language used was Basque or Spanish depending on the schools' linguistic profile.

\subsection{Procedure}

The procedure used to carry out the research consisted of an individual meeting with each child that did not take more than 15 minutes. All the interviews were conducted by the same researcher. Before the meeting, the researcher came into the classroom to introduce him and the activity to be undertaken over the following days.

The protocol designed to hold the meetings is consistent with similar studies involving very young children's understanding of scientific concepts (i.e. Villarroel, Miñón \& Nuño, 2011) and it is as follows:

The first part of the meeting consisted of a motivational phase. The interviewer began by reminding children about the targeted theme of the activity, rainfall.

In the case of the participants enrolled in preschool education, the method used to stimulate children's cooperation was a puppet which was made to pretend that it did not know what rain was. So, the interviewer encouraged the participation of children in the interview by explaining that the goal of the meeting was to help the puppet understand what rainfall was and that the way to achieve this would be by having the children give some short explanations which would include a nice drawing. 
Regarding children who were at primary education level, bearing in mind the individual's age, the utilization of a puppet was not considered an appropriate way to stimulate children's participation in the meeting. Instead, the methodology employed in the interview was focused on telling children the great interest that the interviewer had in finding out what children had to say about rain and also, on highlighting the importance of children's participation and the role of their drawings.

The second part of the meeting was a dialogue that started as soon as the child expressed his or her predisposition to be involved in the task. The interviewer used the following questions to carry out the conversation:

- Have you ever seen rain? (no informative question)

- (1) Where does rain come from?

- (2) Where does rain go after it falls?

- (3) Sometimes after it rains there are puddles but eventually they disappear. What happens to these puddles?

- Have you ever seen clouds? (no informative question)

- (4) What do clouds consist of?

A very similar set of questions was used in the study developed by Saçkes' team (Saçkes et al., 2010) in order to examine young children's understanding of the precipitation phenomena, a study that employed questions based on key concepts identified by Miner (1992).

These crucial notions seem to vary essentially around the following key conceptual notions: (a) establishing the relationship between the phenomenon of rain and clouds, (b) grasping what happens with the passage of rainwater when it falls to the earth's surface, (c) determining the explanations children express to make sense of the cause of the rain and, finally, (d) finding out how the children see the nature and structure of clouds (Saçkes et al., 2010).

After finishing the dialogue concerning the aforementioned questions, the final part of the meeting began by proposing that children draw a picture of rain. During this work the interviewer continuously encouraged children to draw as many items as they wanted to but always focusing on rain and rain related material. To do the drawings, children had at their disposal sheets of paper and some pens and pencils to choose from. It is worth noting that in order not to make the interviews too long no colored pens were made available to the children.

Moreover, as has been pointed out, children's drawings can be used to look into their scientific conceptions solely when one takes into consideration the meaning that subjects themselves give to their own depictions (Karin, 2009). For this reason, during the drawing task children were often encouraged to express what they were drawing and what they wanted to represent. Additionally, before finishing the meeting and once the participants decided that the drawing was completed interviewer and child, working together, reviewed the meaning of all the elements drawn, taking note of the meaning of all the parts of the picture.

Interestingly, very few children refused to take part in the activity. In fact, all the children whose data was considered for this study enthusiastically agreed to partake in the tasks. Indeed, they usually demonstrated significant interest towards the activity, especially concerning the artistic efforts.

Each interview was audio-recorded and the corresponding transcription was collected together with the drawing done and data regarding the child's educational level, sex and school.

This research protocol earned the support of the advisory team of the Centre for the Support of Educational Innovation and Training for non-university learning within the Department of Education of the Basque Government and it was also agreed and approved by the principal of each of the schools involved in this study.

Additionally, the parents and caretakers of the children who were involved in the research were informed in writing by the direction board of each school regarding the objectives and method of the study and also concerning the procedure for expressing the wish not to participate in the research. Nobody among the families whose children were to take part in the study refused to cooperate with the research project.

\subsection{Data Analysis}

To discover patterns of the participants' understanding of precipitation phenomenon, both the responses to the semi-open ended questions and their corresponding pictures were analysed using the constant comparative method (Glaser \& Strauss, 1967, Boeije, 2002; Strauss \& Corbin, 1994). 
As previously pointed out in the introductory section, the lack of research in the field of young children's conceptions of natural phenomena calls for an explorative approach aimed at seeking a grounded understanding of this topic. In view of this, the constant comparative method seems to be a suitable methodological strategy. According to this inductive method, the results are a generalization of the casual relationships found in the course of the research done. In addition, this method has the following advantage: codes used to generate the categories that lead to the analysis of the qualitative information are derived from an on-going assessment of the data, rather than from prior hypothesis (Charmaz K. 2005; Hewitt-Taylor, 2001).

Similarly, several explorative studies in fields without an acceptable previous body of evidence have been carried out by virtue of a comparable methodological approach (e.a. Brunk, 2010; Demirbilek \& Tamer, 2010; Lee, Long \& Boore, 2009; Pugh, 2009)

Moreover, the method has been successfully applied to several scientific educational studies; for example, to study students' mental models about concepts in physics (Chiou \& Anderson, 2010), to examine the students' understandings of Lunar concepts (Trundle, Atwood, Christopher \& Sackes, 2010), to evaluate the conceptual change in science education (Trundle \& Bell, 2010), in the field of biotechnological knowledge (Gardner, \& Jones, 2010) and, also, in math education (Demirbilek \& Tamer, 2010). Additionally, the constant comparative method has also been used to examine very young children's scientific conceptions (Murphy, Varley \& Veale, 2011; Saçkes et al., 2010) and also, it has been highlighted as a qualitative research strategy in the field of geoscience education (Alles \& Riggs, 2011).

Regarding the present study, the initial framework employed to develop a code system was based on Saçkes' work (Saçkes et al., 2010). On this basis, the same researcher started to contrast Saçkes's categories with the new data coming from the interviews and from the assessment of children's drawings. He added new categories or re-defined them in accordance with the new data collected (Boeije, 2002). Finally when no new categories emerged from the data, all the responses and data that arose from the semi-open questions and pictures were tagged according to the latest version of the achieved code system. The description of the code version achieved in the current study to transform qualitative information into quantitative data is presented in the results chapter of the manuscript.

Finally, the quantitative analysis was carried out via chi-square tests to study the association between nominal variables and via a nonparametric Kruskal-Wallis H-test (Siegel \& Castellan, 1988) for comparison of means (ANOVA variance analysis was not used because the sample did not meet the requirements for such tests).The level of significance used in the study was $p<0.05$, and statistical work was done using the SPSS version 17 software.

\section{Results}

The results concerning the semi-open questionnaire will be introduced at the beginning, and subsequently, the outcomes related to the pictorial task. In both cases, initially the code system employed to classify the responses elicited, and the corresponding frequencies will be presented and then the analysis of the differences between the two educational levels will be examined. Concerning the first point, table 2 presents the patterns of responses elicited for each of the questions asked during the semi-open questionnaire and the category assigned to each response and also the relative frequency of answers in each category.

According to the information collected from the interviews, the second and third questions produced the widest range of responses.

In this regard, children's understanding about where rain goes after falling (second question) varies from a scientific-like-perspective ("natural" category), which coincides to some extent with at least some of the explanations proposed by scientific views on the water cycle, (i.e. rainfall goes to the river, rain is taken by plants, rain goes to the sea by rivers, after falling rainwater goes underground to the sea, the sun dries rainwater) to the simple supposition that water ceases to exist after it falls.

Between these two explanations, two more children's accounts were found where the concept of water transformation after falling to the ground was beyond their comprehension. Nonetheless, they pointed out that rain remains on the ground, without considering the matter further ("situational" category) or rainwater is solely mentioned along with many others ("urban" category).

With respect to the third question, the understanding of what happens to rainwater in puddles, there was a significant variability of responses related to the role that children attributed to the sun in this process.

Some children not only pointed out the sun as an indisputable cause of the disappearance of puddles but they also attempted to define the role that the sun plays in this process. In this vein children mentioned that, i.e.: The 
sun makes water evaporate or the sun dries the water, the sun melts the water.

Table 2. Proposed code system to classify elements found in children's responses

\begin{tabular}{|c|c|c|c|}
\hline Question & Model responses found & $\begin{array}{l}\text { Categories } \\
\text { proposed }\end{array}$ & $\%$ \\
\hline \multirow{3}{*}{$\begin{array}{l}\text { The source of } \\
\text { rainfall } \\
(\mathrm{N}=114)\end{array}$} & "It is from blue." "I do not know." & $\begin{array}{l}\text { Unknown or } \\
\text { unintelligible }\end{array}$ & 4.4 \\
\hline & "It comes from clouds." "Clouds leave rainfall." & Cloud & 54.4 \\
\hline & $\begin{array}{l}\text { "It comes from there [pointing to the sky]." "It comes from } \\
\text { the sky." "From above." }\end{array}$ & Sky & 41.2 \\
\hline \multirow{6}{*}{$\begin{array}{l}\text { Where does } \\
\text { rain go after it } \\
\text { falls? } \\
(\mathrm{N}=114)\end{array}$} & "I do not know." & $\begin{array}{l}\text { Unknown or } \\
\text { unintelligible }\end{array}$ & 1.8 \\
\hline & $\begin{array}{l}\text { "Rainfall goes to the river and from there to the sea." "It } \\
\text { goes underground." "The sun dries it and waterfall is become } \\
\text { vapor." }\end{array}$ & Natural & 14.0 \\
\hline & $\begin{array}{l}\text { "Rain is taken by plants."; "Rain goes to the sea thanks to } \\
\text { rivers." "After falling rainwater goes underground." }\end{array}$ & & \\
\hline & "It falls to the ground." "It goes down." "It makes puddles." & Situational & 59.6 \\
\hline & $\begin{array}{l}\text { "Rainfall disappears through the sewer and then goes to the } \\
\text { houses by pipes." "It falls over the towns." "It wets the } \\
\text { playground." }\end{array}$ & Urban & 23.7 \\
\hline & "It gets lost" "It is destroyed." & Disappearing & 0.9 \\
\hline \multirow{5}{*}{$\begin{array}{l}\text { Why do } \\
\text { puddles } \\
\text { disappear? } \\
(\mathrm{N}=114)\end{array}$} & "I do not know." & $\begin{array}{l}\text { Unknown or } \\
\text { unintelligible }\end{array}$ & 12.3 \\
\hline & $\begin{array}{l}\text { "Because the sun dries the water." "Because the sun melts } \\
\text { the water." "Because the sun makes water disappear." }\end{array}$ & Sun-made & 52.6 \\
\hline & "Because the Sun rises." "Because the Sun appears." & $\begin{array}{l}\text { Sun } \\
\text { process }\end{array}$ & 15.8 \\
\hline & $\begin{array}{l}\text { "Because puddles are dried." "Because water changes." } \\
\text { "Because puddles become waterless." }\end{array}$ & $\begin{array}{l}\text { Process } \\
\text { Sun }\end{array}$ & 7.9 \\
\hline & $\begin{array}{l}\text { "Water goes through sewers." "Because water gets lost." } \\
\text { "Because water is destroyed." }\end{array}$ & Non natural & 11.4 \\
\hline \multirow{3}{*}{$\begin{array}{l}\text { What do } \\
\text { clouds consist } \\
\text { of? } \\
(\mathrm{N}=110)\end{array}$} & "I do not know." & $\begin{array}{l}\text { Unknown or } \\
\text { unintelligible }\end{array}$ & 30.9 \\
\hline & $\begin{array}{l}\text { "They consist of water." "Clouds consist of steam." "They } \\
\text { consist of fog." }\end{array}$ & Water & 23.6 \\
\hline & "They are made of cotton." "They are made of sugar." & $\begin{array}{l}\text { Other } \\
\text { substances }\end{array}$ & 45.5 \\
\hline
\end{tabular}

Taking into consideration that in these explanations the agent of the physical transformation of water, the sun, is clearly identified and, also, that these children's accounts involve the process that water goes through, evaporation, even though sometimes children did not manage to define it correctly, it may be considered that, to some extent, these explanations match the basic scientific understanding of the notion of the water cycle ("sun-made" category).

In contrast, some explanations solely involved the sun (i.e.: it is because the sun, it happens because the sun appears, because the sun rises) without mentioning any process involving the water of puddles. These were considered a different class ("sun w/o process" category) given that, though the agent of the action is mentioned, no attempt was made with reference to changes in the states of matter. 
Likewise, some explanations were found in which rainwater was linked to a transformation process but no mention was made with respect to the agent of the transformation, the sun (i.e.: "Water got dried"). Consequently, a different category ("process w/o sun") was given as answers. Finally some children tried to explain what happened with puddles by virtue of urban facilities (pipes and sewers) or merely mentioning that water gets lost or it disappears; this was considered as a different group of descriptions ("non natural" category).

Referring to the questions that gave the least variability of responses, the issue on the source of rainwater reveals two distinguishable explanations in the sample studied (apart from the "Unknown or unintelligible" category): most of the subjects interviewed undoubtedly pointed out clouds as the origin of rainfall ("cloud" category) but a significant amount of children linked the origin of rainfall to the sky or to a general supposition, causally saying "above" ("sky" category).

Similarly the matter of the composition of clouds offered two differentiable descriptions: those who mentioned that clouds consisted of water, even though water may be mentioned in different matter of stages (vapour, ice...) and those who considered that clouds were made of other substances like cotton, sugar and so on.

Regarding the differences between the responses given by children from different educational levels (final course of pre-school education, 5-6 years old children, and first course of primary education, 6-7 years old) to the questions of the interview, it must be noted that no statistically significant differences were found.

Moving on to the results of the study of the children's drawings, they were analysed with regard to their content, number and type of pictorial elements drawn (some example of the drawings analysed are presented in the appendix at the end of the paper). Similar procedures have been used to examine children's drawings related, for example, to hydrological concepts (Dove et al., 1999), concepts on plants (Köse, 2008) and the biodiversity of forests (Snaddon, et al. 2008).

Table 3. Proposed code system to classify pictorial elements found in children's drawings

\begin{tabular}{|c|c|c|}
\hline & Elements found in children's drawings & Categories assigned \\
\hline \multirow{5}{*}{ Water cycle } & The sun & Solar \\
\hline & Clouds, river, sea, lake and steam. & Water reservoirs \\
\hline & Soil, mountains, sky, caves, & Geographic \\
\hline & $\begin{array}{l}\text { Rainfall, snow, hail, thunders, storms, } \\
\text { rainbow, wind. }\end{array}$ & Atmospheric \\
\hline & Flowers, grass, trees, leaf. & Living beings \\
\hline \multirow{4}{*}{$\begin{array}{l}\text { No water cycle } \\
\text { related }\end{array}$} & Pipes, sewers, houses, roads, cars, swings. & Urban \\
\hline & Moon, starts, planets. & Astronomic \\
\hline & Angels & Religious \\
\hline & Relatives, children, pets. & People \\
\hline
\end{tabular}

Consequently, all the features displayed in each individual composition were registered and classified in accordance to the categories that emerged from the examination of all the pictures of the sample $(\mathrm{N}=124)$. Table 3 shows the different pictorial elements found, the category assigned and whether the component drawn by the child agrees with the scientific perspective on water cycle.

In examining the differences between children from different educational levels, firstly, the following factors were considered (a) the individual frequency of total drawn elements linked to the scientific perspective of water cycle and (b) the individual frequency of total elements drawn that cannot be included in the water cycle. Table 4 shows the descriptive statistics of these frequencies into each educational group. 
Table 4. Descriptive statistics of frequencies of the water-cycle related to pictorial elements and non related water-cycle elements at each educational level

\begin{tabular}{llll}
\hline & $\begin{array}{l}\text { Last course of pre-school } \\
\text { education }(\mathrm{N}=70) \\
\text { Mean ; SD }\end{array}$ & $\begin{array}{l}\text { First course of primary } \\
\text { education }(\mathrm{N}=54) \\
\text { Mean } ; \mathrm{SD}\end{array}$ \\
\hline $\begin{array}{l}\text { Water cycle }(*) \\
\begin{array}{l}\text { No water cycle } \\
\text { related }\end{array}\end{array}$ & $3.8 ; 1.71 ; 1.4$ & $4.5 ; 1.8$ \\
\hline
\end{tabular}

The above-mentioned differences between children from different educational levels are statistically significant (Kruskal-Wallis H-test $=5.2$ [1]; $\mathrm{p}<0.05$ ) solely in the case of water-cycle related pictorial elements.

Then the differences between drawings carried out by children of different levels were investigated. The elements related specifically to the water cycle were considered and the frequencies of the drawings of the following four water-cycle related categories: "solar", "water reservoirs", "geographic", "atmospheric", "living beings" were examined.

The key elements of difference between drawings from children in the final course of pre-school education (5-6 year old children) and children from first course of primary education (6-7 year old) were (a) the frequency of times they drew the Sun (Chi-Square $=7.2[1] ; \mathrm{p}<0.01)$ and (b) the number of elements drawn assigned to the category of water reservoirs (Kruskal-Wallis H-test=5.2 [1]; $\mathrm{p}<0.01$ ). The corresponding statistical data are shown in tables 5 and 6.

Table 5. Relative frequency (\%) of pictures in which sun is drawn in each educational level

\begin{tabular}{lll}
\hline & Drawing w/o sun & The sun is drawn \\
\hline Last course of pre-school education, 5-6 year old $(\mathrm{N}=70)$ & 70 & 30 \\
First course of primary education, 6-7 year old $(\mathrm{N}=54)$. & 38,9 & 61.1 \\
\hline
\end{tabular}

Table 6. Relative frequencies of pictures of water reservoirs in each educational level

\begin{tabular}{lll}
\hline & $\begin{array}{l}\text { Final course of pre-school education } \\
(\mathrm{N}=70) \\
\mathrm{M} ; \mathrm{SD}\end{array}$ & $\begin{array}{l}\text { First course of primary education } \\
(\mathrm{N}=54) \\
\mathrm{M} ; \mathrm{SD}\end{array}$ \\
\hline Reservoirs of water & $1.4 ; 0.7$ & $1.9 ; 0.9$ \\
\hline
\end{tabular}

\section{Discussion}

With respect to the drawing task, the aforementioned results suggest that when compared to 5-6 year old children (final course of preschool education level), 6-7 year old children (first course of primary education level) draw different pictures regarding the rainfall issue. These differences are connected to two pictorial elements: the sun and the water reservoirs.

More specifically, when children are encouraged to draw a depiction of as many elements related to rainfall as they consider necessary to explain what this atmospheric phenomenon is, children at an upper educational level show a more significant tendency to include the sun as one of these rainwater related elements. Additionally they also draw rivers, sea, clouds, vapour and lakes more frequently.

However, no difference has been found in reference to other characteristic elements of children's drawings, linked to either water-cycle related features (geographic, atmospheric and living beings) or other types of elements such as people, religious, astronomic or urban issues.

These findings could bear out the conclusion that according to the pictorial illustrations that children produce during their elementary education, at some time between 5 and 7 years of age children achieve a more advanced 
conceptual level in the understanding of the mechanism of rainwater (and consequently the notion of the water cycle) by enriching their internal representation of this atmospheric event with new agents: the sun and water reservoirs.

However, it still seems surprising that the analysis of responses to the semi-open questionnaire does not show any difference between 6-7 year old (first course of primary education level students) and 5-6 year old children (the final level course of preschool education).

In this regard when children were asked about the cause of the disappearance of puddles, $68 \%$ of them explicitly mentioned the sun. This clearly indicates that, to some extent, a significant majority of the subjects questioned know that the sun is involved in some of the changes linked to rainwater. Unexpectedly, according to the data of this study, both groups of children (the first course of primary education, 6-7 year old, and the final course of preschool education level, 5-6 year old) similarly relied on the sun to facilitate their oral explanations. However, only the more advanced aged children developed their pictographic representations about the rainfall process taking into consideration the sun, unlike the younger students.

This observation may suggest that children's oral expressions and their pictorial productions of their knowledge represent different levels of conceptual understanding of the mechanisms of rainwater.

With respect to this finding, it may be worth underlining that children's pictorial productions are considered to be in direct correspondence to their mental representations (Cherney, Seiwert, Dickey, \& Flichtbeil, 2006; Kress, Jewitt, Ogborn \& Tsatsarelis, 2001). Additionally, research techniques grounded on drawings are useful to prevent children from matching conventional responses based on what children may consider acceptable for the interviewer (Rennie \& Jarvis, 1995).

As a results, as far as this research project is concerned, it seems reasonable to assume that children's pictorial representations are a more precise reflection of the real status of their understanding process regarding the phenomenon of rain. This assumption is in tandem with the observed fact that while oral productions are similar among all the children included in the sample study; the content of the drawings are substantially different among children at different developmental stages.

Moreover, the difference mentioned is related to the consideration of the sun as a rainwater related element. This point does not seem to be a notion easily understood by children along their learning curve, given that little perceptual evidence is found in everyday life to support this abstract conception.

Summarizing, the recognition of an abstract relationship between the sun and rain is a characteristic feature that distinguishes conceptual understanding of rainfall among the children from the different educational levels considered in this study. In this sense, more advanced aged individuals depict this relationship both in their pictorial and oral explanations. However, the youngest children (5-6 year old children enrolled in the final course of preschool education level) do not reflect the assumption of this relationship in their drawings but they do exteriorize a preliminary understanding of it in their verbal productions when they need to account for events related to rainwater.

These questions move on to the most general issue related to the necessity of discussing what general cognitive developmental theory might be suitable to coordinate the results presented here.

In this respect, it does not seem acceptable to assume that children can grasp the singular role that the sun plays in the water cycle by themselves. As previously mentioned, the sun's role is an abstract notion which does not turn out to be easily accessible to young children. On the contrary, it seems to be more appropriate to consider that the continuous cultural activity in which children are involved, both at school and at home, is the origin of this knowledge.

Consequently, the educational perspective on the interpretation of atmospheric phenomena, and rainfall in particular, should be considered as a social construction that aims to provide individuals with the conceptual resources necessary to assure effective communication by means of the scientific community's communication patterns. In this vein and paraphrasing the conclusions emerging in related educational fields (Sfard, 2001; Tiedemann \& Brandt, 2010), the process of school learning of the interpretation of natural phenomena that science brings, corresponds to the process of becoming fluent in communicative practices that would be recognized as genuinely scientific by expert interlocutors.

These ideas connect with Rogoff's theory (1990) of learning and more specifically with the so-called 'appropriation' concept. This concept refers to the idea that learning is a process that involves learners in the use of cultural resources provided by other people which, in turn, allows them to achieve a shared focus of attention and develop shared meanings. 
Interestingly a socio-cultural perspective that assumes learning is mediated by social interaction highlights the role of language in the construction of abstract objects through communicative interaction. More specifically, it is believed that in the process of the emergence of new mental abstract objects, the individual goes through a linguistic templates-driven phase (Sfard, 2000a). The principal feature of this phase is the fact that the individual has not yet understood the complete meaning of the abstract concept. However, the linguistic usages that he or she discovers in the communication exchanges, offers the necessary scaffolding to guide the verbal use of the concept. Thus, the linguistic practice of the abstract concepts and the attempts at utilizing them effectively in terms of success communicative are precisely the way to build progressively the full comprehension of the meaning of these abstract concepts (Sfard, 2000a, 2000b).

This perspective would collocate with the data collected in this study. The discrepancy between oral and pictorial productions registered in the case of the youngest children could be linked to the fact that these subjects are still in the process of the construction of the abstract relationship between the sun and the physical transformations of the water substance.

According to the socio-cultural perspective, the communicative exchanges that children have with more experienced people (teachers and parents) may play the definitive role in the emerging of this intangible notion. Throughout the communicative interaction children would find the necessary linguistic usages that facilitate them a successful communication and these linguistic usages embedded into relevant communicative contexts could represent the critical factor in the process of the developing the understanding of the abstract notions (Sfard, 2000a, b), in this case, related to rainfall phenomenon.

Furthermore, it may be stated that, according to both their verbal and graphic responses, more advanced aged children have completed, first of all, the process of the construction of the aforementioned abstract relationship between the sun and rainfall and, consequently, that they are finally capable of engaging in communicative practices which eventually will become more similar to the approved scientific discourse related to the water cycle.

All these considerations may provide significant insights for future research. First of all, further research is required to bear out whether the categories used in this study to analyze children's both verbal answers and drawings turn out to be appropriate in other samples. Moreover, supplementary longitudinal studies are necessary to corroborate whether at some time between the final course of preschool education, 5-6, and the end of the first course of primary education, 6-7, children achieve an understanding of the key, but non-obvious, role that the sun and reservoirs play in the water cycle.

Moreover, it would be necessary to examine in more depth whether the differences between the aforementioned two age groups are definitely more related to pictorial elaborations than to their verbal explanations. To this end, further studies that analyze young children's comprehension of other kinds of natural phenomena may play a definitive role in verifying the worthiness of the socio-cultural perspective in investigations of the conception of natural phenomena during early childhood.

Finally, a significant issue that remains for further research is the role that educational curriculum has as a boost element to the process of grasping the abstract relationships that underlie everyday atmospheric phenomena and, in addition, what educational practices may be more effective in accompanying young children during this process.

\section{References}

Alles, M., \& Riggs, E. M. (2011). Developing a process model for visual penetrative ability. In A. D. Feig, \& A. Stokes (Eds.), Qualitative Inquiry in Geoscience Education Research (pp. 63-80). Boulder: The Geological Society of America.

Bodzin, A. M., Shiner, B., \& Weaver, S. (2010). The Inclusion of Environmental Education in Science Teacher Education. New York: Springer.

Boeije, H. (2002). A purposeful approach to the constant comparative method in the analysis of qualitative interviews. Quality and Quantity, 36, 391-409. http://dx.doi.org/10.1023/A:1020909529486

Brunk, K. H. (2010) Reputation building: Beyond our control? Inferences in consumers' ethical perception formation. Journal of Consumer Behaviour, 9(4), 275-292. http://dx.doi.org/10.1002/cb.317

Bullock, M., Sodian, B., \& Koerber, S. (2009). Doing Experiments and Understanding Science. In W. Schneider, \& M. Bullock (Eds.), Human Development from Early Childhood to early Adulthood (pp. 173-197). New York: Psychology Press. 
Cenoz, J. (1998). Multilingual education in the Basque Country. In J. Cenoz, \& F. Genesse (Eds.), Beyond bilingualism: Multilingualism and multilingual education (pp. 175-191). Clevedon: Multilingual Maters Ltd.

Charmaz, K. (2005). Grounded theory in the 21st century. In N. K. Denzin, \& S. L. Yvonna (Eds.), The Sage Handbook of Qualitative Research (pp. 507-537). Thousand Oaks: Sage Publications.

Cherney, I. D., Claire, S. S., Tara, M. D., \& Flichtbeil, J. D. (2006), Children's Drawings: A mirror to their minds. Educational Psychology, 26(1), 127-142.

Chiou, G., \& Anderson, O. R. (2010). A study of undergraduate physics students' understanding of heat conduction based on mental model theory and an ontology-process analysis. Science Education, 9(5), 825-854.

Christidou, V., \& Hatzinikita, V. (2006). Preschool Children's Explanations of Plant Growth and Rain Formation: A Comparative Analysis. Research in Science Education, 36, 187-210. http://dx.doi.org/10.1002/sce.20385

Demirbilek, M., \& Tamer, S. L. (2010). Math teachers' perspectives on using educational computer games in math education. Procedia Social and Behavioral Sciences, 9, 709-716. http://dx.doi.org/10.1016/j.sbspro.2010.12.222

Devereaux, A., Poling, E., \& Evans, E. M. (2004). Are dinosaurs the rule or the exception?: Developing concepts of death and extinction. Cognitive Development, 19(3), 363-383.

Dockrell, J. E., Braisby, N., \& Best, R. M. (2007). Children's acquisition of science terms: Simple exposure is insufficient. Learning and Instruction, 17, 577-594. http://dx.doi.org/10.1016/j.learninstruc.2007.09.005

Dove, J. E., Everett, L. A., \& Preece, P. F. (1999). Exploring a hydrological concept through children's drawings. International Journal of Science Education, 21(5), 485-497. http://dx.doi.org/10.1080/09500699929053

Duschl, R., \& Hamilton, R. (2011). Learning science. In R. E. Mayer, \& P. A. Alexander (Eds.), Handbook of Research on Learning and Instruction (pp. 78-126). New York: Routledge.

Eustat. (2010). Instituto Vasco de Estadística. Schooling rates in the Basque Country by age and level (\%). 2009/10. Retrieved January 22, 2013, from http://en.eustat.es/ci_ci/estadisticas/tema_300/opt_0/tipo_1/ti_Pupils_teachers_and_centres/temas.html\#axz z1bQ4F7y21

Fernández, R., \& Rodríguez, L. M. (2006). Los pequeños de cuatro años en el rincón de ciencias: Qué ven y qué dicen sobre el nacimiento de las plantas. Alambique: Didáctica de las ciencias experimentales, 49, 105-113.

Frappart, S., \& Frède, V. (2010). Where does the stone go when we drop it? Development of french schoolchildren's knowledge of gravity. Advances in Space Research, 45(8), 1058-1066. http://dx.doi.org/10.1016/j.asr.2009.12.013

Gardner, G., \& Jones, M. (2010). Science instructors' perceptions of the risks of biotechnology: Implications for science education. Research in Science Education, 41(5), 711-738. http://dx.doi.org/10.1007/s11165-010-9187-0

Ginsburg, H. P., \& Golbeck, S. L. (2004). Thoughts on the future of research on mathematics and science learning and education. Early Childhood Research Quarterly, 19, 190-200. http://dx.doi.org/10.1016/j.ecresq.2004.01.013

Glaser, B. G., \& Strauss, A. L. (1967). The Discovery of Grounded Theory: Strategies for Qualitative Research. Chicago: Aldine.

Goñi, A., \& Villarroel, J. D. (2005). La comprensión de las propiedades físicas de la materia: Motivación y cambio conceptual. Journal of Science Education, 6(1), 12-15.

Hannust, T., \& Kikas, E. (2010). Young children's acquisition of knowledge about the earth: A longitudinal study. Journal of Experimental Child Psychology, 107(2), 164-180. http://dx.doi.org/10.1016/j.jecp.2010.04.002

Henriques, L. (2002). Children's ideas about weather: A review of the literature. School Science and Mathematics, 102(5), 202-215. http://dx.doi.org/10.1111/j.1949-8594.2002.tb18143.x

Hewitt-Taylor, J. (2001). Use of constant comparative analysis in qualitative research. Nursing Standard, 15(42), $39-42$. 
Holliday, E. L., Harrison, L. J., \& McLeod, S. (2009). Listening to children with communication impairment talking through their drawings. Journal of Early Childhood Research, 7(3), 244-263. http://dx.doi.org/10.1177/1476718X09336969

Inan, H. Z., Trundle, K. C., \& Kantor, R. (2010). Understanding Natural Sciences Education in a Reggio Emilia-Inspired Preschool. Journal of Research in Science Teaching, 47(10), 1186-1208. http://dx.doi.org/10.1002/tea.20375

Karin, E. (2009). Drawings as representations of children's conceptions. International Journal of Science Education, 31(1), 41-57.

Kloos, H., Fisher, A., \& Van Orden, G. C. (2010). Situated naïve physics: Task constraints decide what children know about density. Journal of Experimental Psychology: General, 4, 625-637. http://dx.doi.org/10.1037/a0020977

Köse, S. (2008). Diagnosing Student Misconceptions: Using Drawings as a Research Method. World Applied Sciences Journal, 3(2), 283-293.

Kress, G., Jewitt, C., Ogborn, J., \& Tsatsarelis, C. (2001). Multimodal Teaching and Learning: The Rhetorics of the Science Classroom. London: Continuum.

Larrea, K. (2009). Grammatical errors in students: A proposal to solve them. Revista de Piscodidáctica, 14(1), 63-78.

Lee, S. C., Long, A., \& Boore, J. (2009). Taiwanese women's experiences of becoming a mother to a very-low-birth-weight preterm infant: A grounded theory study. International Journal of Nursing Studies, 46(3), 326-336. http://dx.doi.org/10.1016/j.ijnurstu.2008.10.004

Lewis, E. B., van der Hoeven, K. J., Bueno, N., Baker, D. R., Wilson, M. J., \& Lang, M. (2010). Elementary Teachers' Comprehension of Flooding through Inquiry-based Professional Development and Use of Self-regulation Strategies. Faculty Publications: Department of Teaching, Learning and Teacher Education. Paper 125. Retrieved January 22, 2013, from http://digitalcommons.unl.edu/teachlearnfacpub/125

Losh, S. C., Wilke, R., \& Pop, M. (2007). Some Methodological Issues with "Draw a Scientist Tests" among Young Children. International Journal of Science Education, 30(6), 773-792. http://dx.doi.org/10.1080/09500690701250452

Márquez, C., \& Bach, J. (2007). Una propuesta de análisis de las representaciones de los alumnos sobre el ciclo del agua. Enseñanza de las Ciencias de la Tierra, 15(3), 280-286.

Márquez, C., Izquierdo, M., \& Espinet, M. (2003). Comunicación multimodal en la clase de ciencias: El ciclo del agua. Enseñanza de las Ciencias, 21(3), 371-386.

McNair, S., \& Stein, M. (2001). Drawing on their understandings: Using illustrations to invoke deeper thinking about plants. Proceedings of the 2001 Annual: International Conference of the Association for the Education of Teachers in Science. Costa Mesa, CA: Association for the Education of Teachers in Science.

Miner, J. T. (1992). An early childhood study of the water cycle. Unpublished Master of Art Thesis, University of Nevada: Las Vegas, NV.

Murphy, C., Varley, J., \& Veale, A. (2012). I'd rather they did experiments with us... than just talking: Irish Children's views of primary school science. Research in Science Education, 42(3), 415-438. http://dx.doi.org/10.1007/s11165-010-9204-3

Panagiotaki, G., Nobes, G., \& Potton, A. (2009). Mental models and other misconceptions in children's understanding of the earth. Journal of Experimental Child Psychology, 104, 52-67, http://dx.doi.org/10.1016/j.jecp.2008.10.003

Plasencia, I., \& Varela, C. (2006). El proyecto Spectrum: Aplicación y actividades de aprendizaje de ciencias en el primer ciclo de la. Educación Primaria. Revista de Educación, 339, 947-958.

Prokop, P., \& Fancovicová, J. (2006). Students' ideas about the human body: Do they really draw what they know? Journal of Baltic Science Education, 2(10), 86-95.

Pugh, D. (2009). The phoenix process: a substantive theory about allegations of unprofessional conduct. Journal of Advanced Nursing, 65(10), 2027-2037. http://dx.doi.org/10.1111/j.1365-2648.2009.05038.x

Rennie, L. J., \& Jarvis, T. (1995). Children's choice of drawings to communicate their ideas about technology. Research in Science Education, 25, 239-252. 
Reyero, C., Calvo, M., Vidal, M. P., García, E., \& Morcillo, J. G. (2007). The illustrations of the water cycle in Primary Education textbooks. Enseñanza de las Ciencias de la Tierra, 15(3), 287-294.

Rogoff, B. (1990). Apprenticeship in Thinking: Cognitive Development in Social Contex. Oxford University Press: New York.

Saçkes, M., Flevares, L. M., \& Trundle, K. C. (2010). Four- to six-year-old children's conceptions of the mechanism of rainfall. Early Childhood Research Quarterly, 25(4), 536-546. http://dx.doi.org/10.1016/j.ecresq.2010.01.001

Salaburu, P. (2009). Bolonia: Una oportunidad que no podemos perder. Revista de Psicodidáctica, 14(2), 169-176.

Schroeder, M., Graham, S. A., McKeough, A., Stock, H., \& Palmer, J. (2010). Gender differences in preschoolers' understanding of the concept of life. Journal of Early Childhood Research, 8(3), 227-238. http://dx.doi.org/10.1177/1476718X10366766

Sfard, A. (2000a). Steering, discourse between metaphors and rigor: Using focal analysis to investigate an emergence of mathematical objects. Journal for Research in Mathematics Education, 31(3), 296-327.

Sfard, A. (2000b). Symbolizing mathematical reality into being. In K. Cobb, E. Yackel, \& K. McClain (Eds.), Symbolizing and communicating in mathematics classrooms: Perspectives on discourse, tools, and instructional design (pp. 37-98). Mahwah, NJ: Erlbaum.

Sfard, A. (2001). Learning mathematics as developing a discourse. In Speiser R, Maher C, \& Walter C, (Eds.), Proceedings of 21st Conference of PME-NA (pp. 23-44). Columbus, Ohio: Clearing House for Science, mathematics, and Environmental Education.

Shepardson, D. P., Harbor, J., \& Wee, B. (2005). Water Towers, Pump Houses, and Mountain Streams: Students' Ideas about Watersheds. Journal of Geoscience Education, 53(4), 381-386.

Shepardson, D. P., Wee, B., Priddy, M., Schellenberger, L., \& Harbor, J. (2009). Water Transformation and Storage in the Mountains and at the Coast: Midwest students' disconnected conceptions of the hydrologic cycle. International Journal of Science Education, 31(11), 1447-1471. http://dx.doi.org/10.1080/09500690802061709

Siegel, S., \& Castellan, N. J. (1988). Nonparametric statistics for the behavioral sciences. New York: McGraw-Hill.

Snaddon, J. L., Turner, E. C., \& Foster, W. A. (2008). Children's Perceptions of Rainforest Biodiversity: Which Animals Have the Lion's Share of Environmental Awareness? PLoS ONE, 3(7), e2579. http://dx.doi.org/10.1371/journal.pone.0002579

Straatemeier, M., van der Maas, H. L. J., \& Jansen, B. R. J. (2008). Children's knowledge of the earth: A new methodological and statistical approach. Journal of Experimental Child Psychology, 100, 276-296. http://dx.doi.org/10.1016/j.jecp.2008.03.004

Strauss, A., \& Corbin, J. (1994). Grounded theory methodology: An overview. In N. K. Denzin, \& Y. S. Lincoln (Eds.), Handbook of qualitative research (pp. 273-285). London: Sage Publications.

Strommen, E. (1995). Lions and tigers and bears, Oh my! Children's conceptions of forests and their inhabitants. Journal of Research in Science Teaching, 32, 683-698.

Tiedeman, K., \& Brandt, B. (2010). Parents' Support in Mathematical Discourses. Proceedings of the 6th International Conference on Mathematics Education and Society (pp. 457-468). Berlin: Freien Universität.

Trundle, K. C., \& Bell, R. L. (2010). The use of a computer simulation to promote conceptual change: A $\begin{array}{lllll}\text { quasi-experimental study. } \quad \text { Computers } & \text { Education, }\end{array}$ http://dx.doi.org/10.1016/j.compedu.2009.10.012.

Trundle, K. C., Atwood, R. K., \& Christopher, J. E. (2007). Fourth grade elementary students' conceptions of standards-based lunar concepts. International Journal of Science Education, 29(5), 595-616.

Trundle, K. C., Atwood, R. K., Christopher, J. E., \& Sackes, M. (2010). The effect of guided inquiry-based instruction on middle school students' understanding of lunar concepts. Research in Science, Education, 40(3), 451-478, http://dx.doi.org/10.1080/09500690600779932.

Uyen, L., Payne, D. L., \& Whitley, L. (2010). Research on Learning and Teaching Ocean and Aquatic Sciences. NMEA Special Report, 3, 22-26. 
Villarroel, J. D., Miñón, M., \& Nuño, T. (2011). The origin of counting: A study of the early meaning of 'one', 'two' and 'three' among Basque- and Spanish-speaking children. Educational Studies in Mathematics, 76(3), 345-361. http://dx.doi.org/10.1007/s10649-010-9291-0.

Vosniadou, S., \& Brewer, W. F. (1994). Mental models of the day/night cycle. Cognitive Science, 18, $123-184$.

White, R. T., \& Gunstone, R. F. (1992). Probing understanding. London, UK: Falmer Press.

Zimmerman, C. (2007). The development of science thinking skills in elementary and middle school. Developmental Review, 27(2), 172-223.

\section{Appendix}
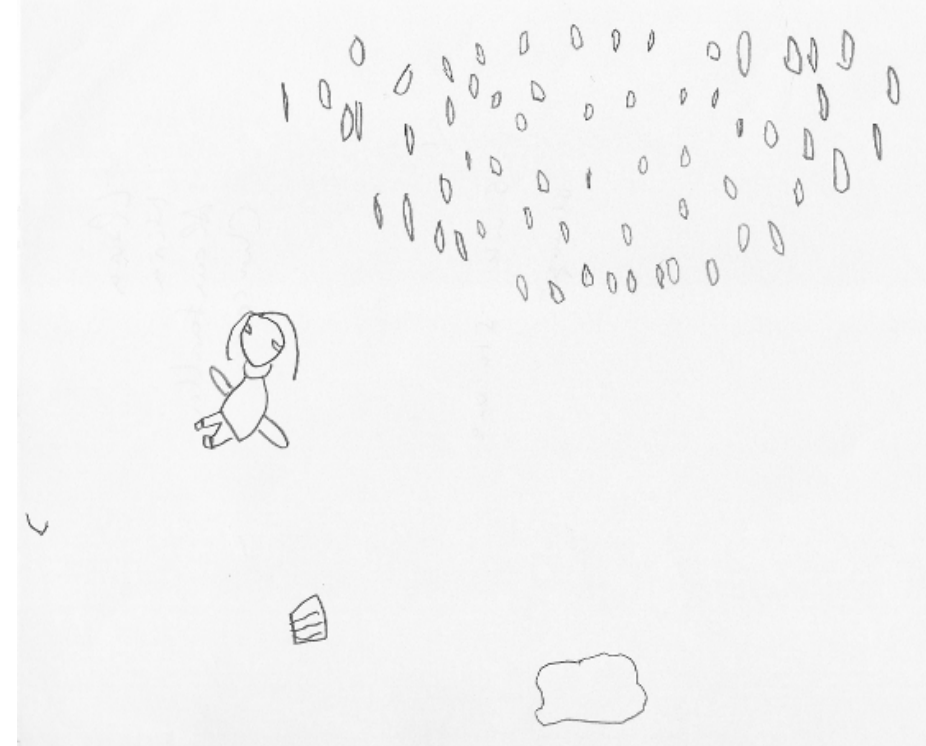

00000000

Figure 1. A drawing of a 5 year old child representing rainfall

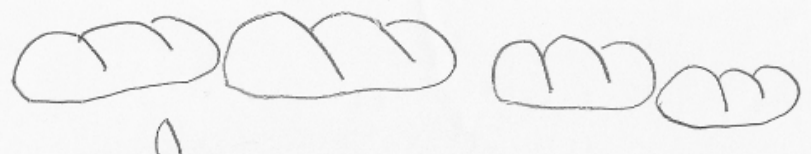

o

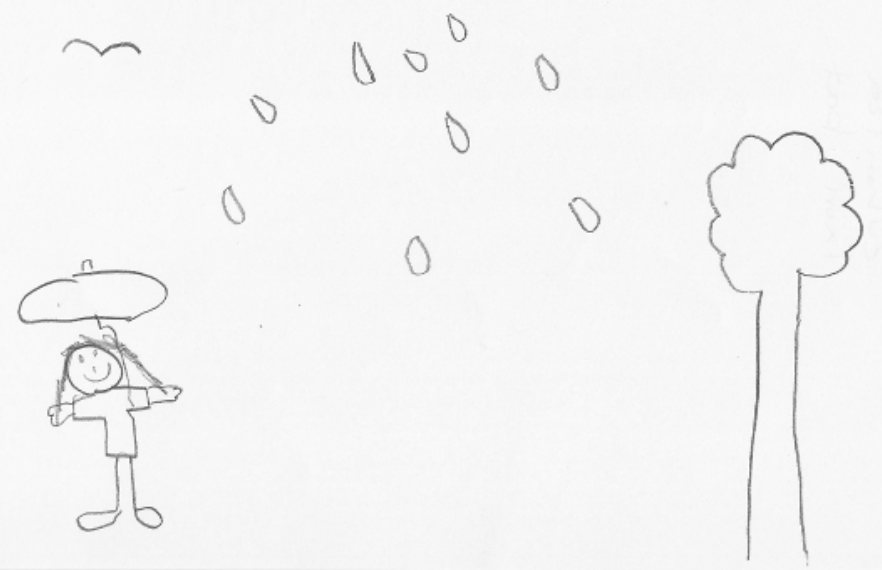

Figure 2. A drawing of a 5 year old child representing rainfall 


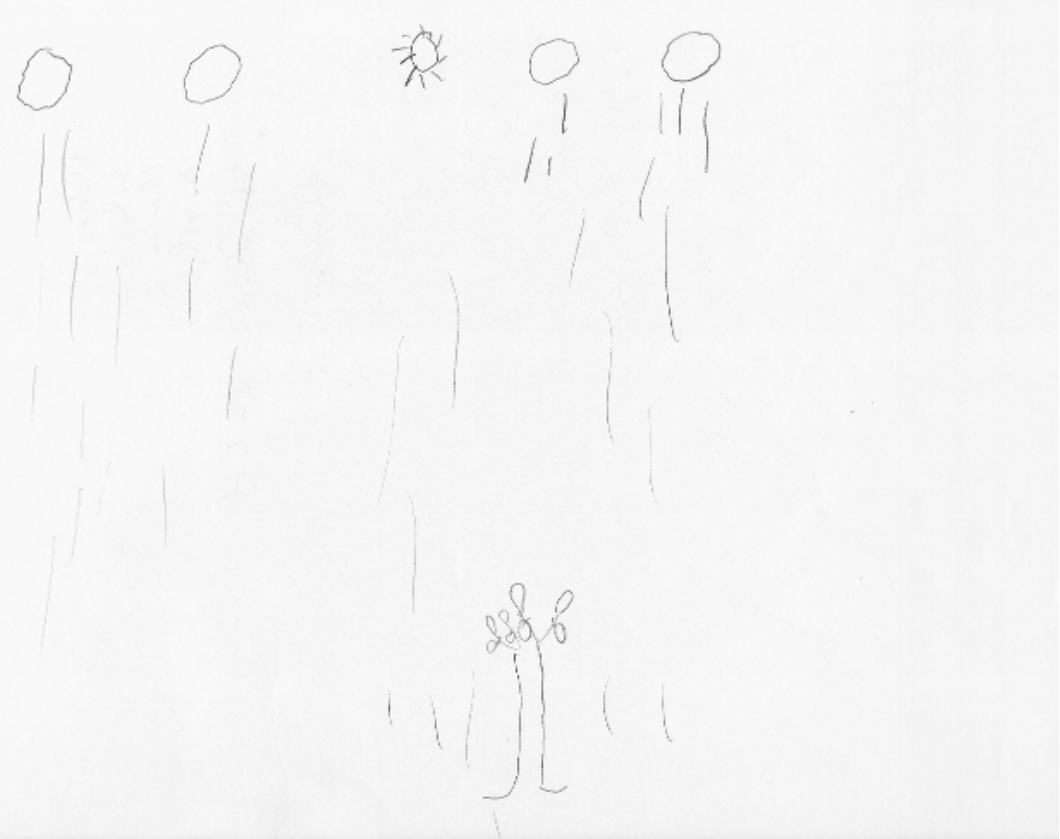

Figure 3. A drawing of a 6 year old child representing rainfall

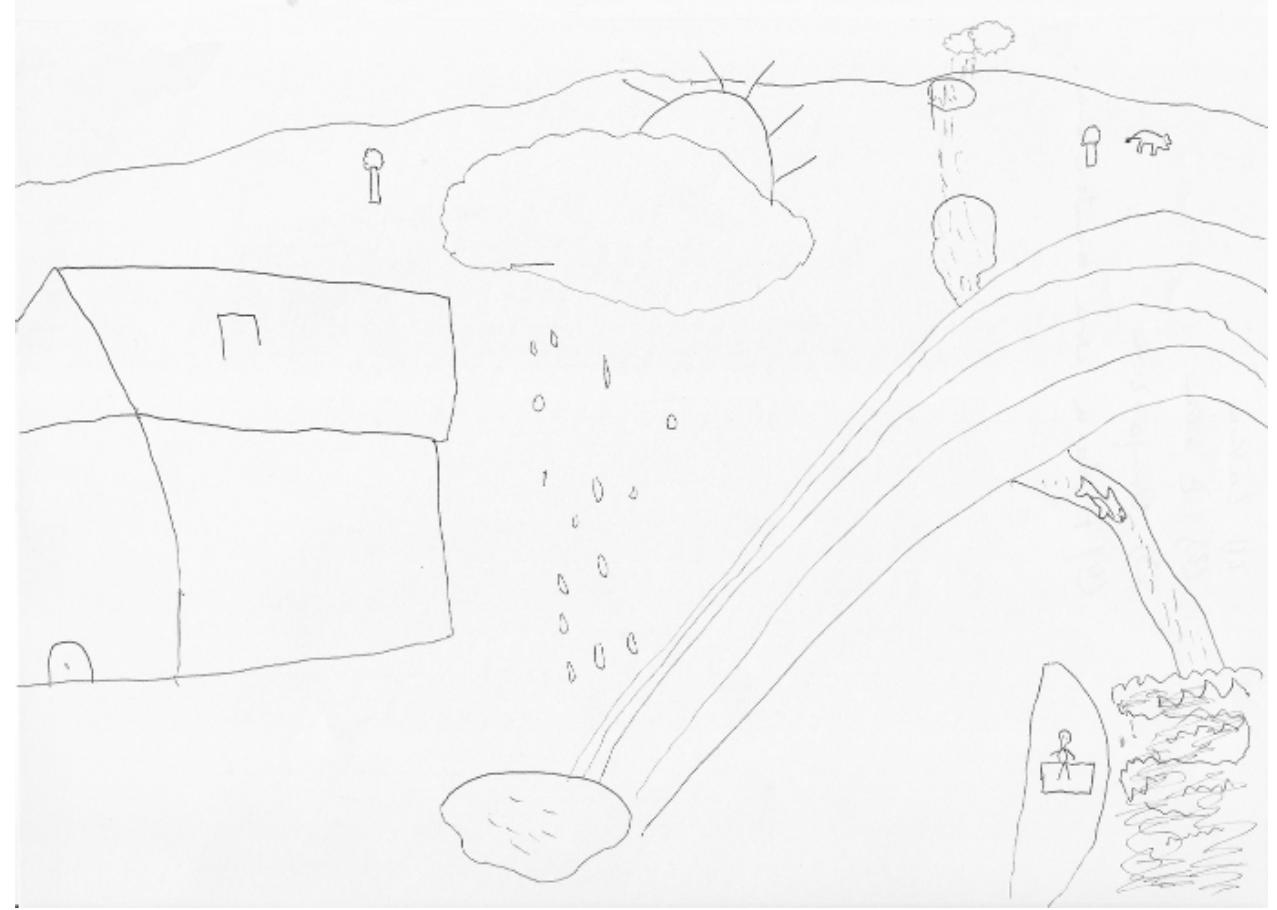

Figure 4. A drawing of a 7 year old child representing rainfall

\section{Copyrights}

Copyright for this article is retained by the author(s), with first publication rights granted to the journal.

This is an open-access article distributed under the terms and conditions of the Creative Commons Attribution license (http://creativecommons.org/licenses/by/3.0/). 